\title{
LEED GOLD BUT NOT EQUAL: TWO CASE STUDY BUILDINGS
}

\author{
F.D.F. BAJA, S. BAJRACHARYA, M.A. FREEMAN, A.J. GRAY, B.T. HAGLUND, H.R. KUIPERS \& \\ O.R. OPATOLA \\ Architecture Program, University of Idaho, USA.
}

\begin{abstract}
The layman's perception is that Leadership in Energy and Environmental Design (LEED) and Building Research Establishment Environmental Assessment Method (BREEAM) certified buildings are inherently green, eco-friendly, and sustainable. In the architectural community, there is widely held recognition of the shortcomings of LEED and its UK relative BREEAM. The upstart Cascadia Chapter of the USGBC factored in the creation of the more ecologically articulate Living Building Standard. In the UK Mark Skelly, Director, Skelly \& Crouch, echoes this notion, 'BREEAM is useful for setting a brief for clients or planners who don't know much about sustainability. But when a client is interested in the design process and has an intelligent brief tailored to its needs and function, a rigid adoption of a BREEAM target can get in the way of the true beauty of creating and making. BREEAM plays an important role in the industry, but it is no substitute for a thoughtful iterative briefing and design process.' The University of Idaho campus has recently added two LEED Gold buildings - one a new research laboratory and the other an extensively remodelled classroom building. Over the last two years, teams of graduate students have performed post-occupancy evaluations of these buildings with foci on daylighting, energy use, occupant comfort, and ecological fitness. In the course of these studies university facilities staff were interviewed, occupants surveyed, daylighting and glare analyses performed, actual energy compared to modelled use, design alternatives explored, and life cycle cost analyses performed. This paper will present comparative results for the two buildings and shows that equal LEED ratings do not guarantee equal ecological performance, and in fact, can be attributed to widely divergent ecological performers.
\end{abstract}

Keywords: BREEAM, daylight analyses, energy modelling, LEED, post-occupancy evaluation, user surveys.

\section{INTRODUCTION}

This year the authors focused on thermal and visual comfort issues in the newly remodelled Education Building. Their findings build on previous studies of lighting conditions in both Education and the newly constructed Integrated Research and Innovation Center (IRIC) [1], [2]. For IRIC the university magazine claims, 'It's bright and open, with daylight streaming in from all angles in common areas, offices, and laboratories. Glass-walled conference rooms line IRIC's three-story atrium, which overlooks the campus mall and includes an enormous door that can open the lobby to the outside pavilion on nice days [3].' For the Education Building the university magazine reports, 'The building is LEED certified by U.S. Green Building Council to increase efficiency and sustainability. Natural light penetrates all spaces' [4]. Although the design intent of both buildings sounds similar, the execution was startlingly different. The Education Building replaced near-opaque façades with unshaded curtain walls, while the IRIC protected apertures with external shading devices.

IRIC was found to have minor visual and thermal comfort issues, largely because its south façade is protected by an external perforated metal screen and its west façade is protected by an external retractable louver system. This year three teams of investigators were interested in why the Education Building underperforms in comparison to its fellow LEED Gold-rated IRIC. Ironically, neither building earned LEED points for daylighting. The analysis work and suggested 
improvements by the three investigation teams is presented as sections 2, 3, and 4 of this paper. They used an assortment of analytical tools - data loggers, hand-held infrared temperature sensors, infrared cameras, glare analysis software, thermal and lighting analysis software, cloud-bases user surveys, and direct observation. The comparison to the more successful IRIC will be limited to the conference presentation due to spatial constraints for this paper.

\section{HUMAN COMFORT IN THE WEST-FACING SPACES}

The daylighting performance of the Education Building since its renovation in 2016, though improved from under lighted to over lighted, still has visually and thermally uncomfortable west- and south-facing study spaces. The L-shaped building plan, has five floors with floor-to-ceiling curtain wall as its west and the south façades. The direct sunlight in the west-facing study spaces in the afternoon/evening has the potential of reducing the number users of these spaces.

Hypothesis: The western study space is used more in the morning hours.

\subsection{Methodology}

Activities that take place in the west-facing wing of the building were observed. In this study, most of the spaces are classrooms with adjacent study spaces in the wide west-facing hallways. The study was limited to the second and fourth floors, which are most used (Fig. 1). Also, the class schedule shows that more classes are held between noon and 1pm, which increases the potential study space use during this time. Data loggers were placed in two different locations on the 2 nd and 4th floor towards the western edge of the study spaces near the windows. The hobo data loggers collected the temperatures and relative humidity of the space at 30-minute intervals. From the readings, it can be seen that the temperature of the lobby rises from 9 am to noon, to $6 \mathrm{pm}$, while relative humidity dropped by 20-25\% during these hours. This change is due to increased activity and solar gain during afternoon hours.

Using the Infrared Camera set for the default emissivity of most building materials, the surface temperature of the plastic lounge chair in this lobby measures as high as $116^{\circ} \mathrm{F} / 47^{\circ} \mathrm{C}$ and the concrete floor $84^{\circ} \mathrm{F} / 29^{\circ} \mathrm{C}$ on a sunny $\sim 50^{\circ} \mathrm{F} / 10^{\circ} \mathrm{C}$ spring day, which is thermally uncomfortable for its users (Fig. 2). Also, reflective surfaces like the polished concrete floor

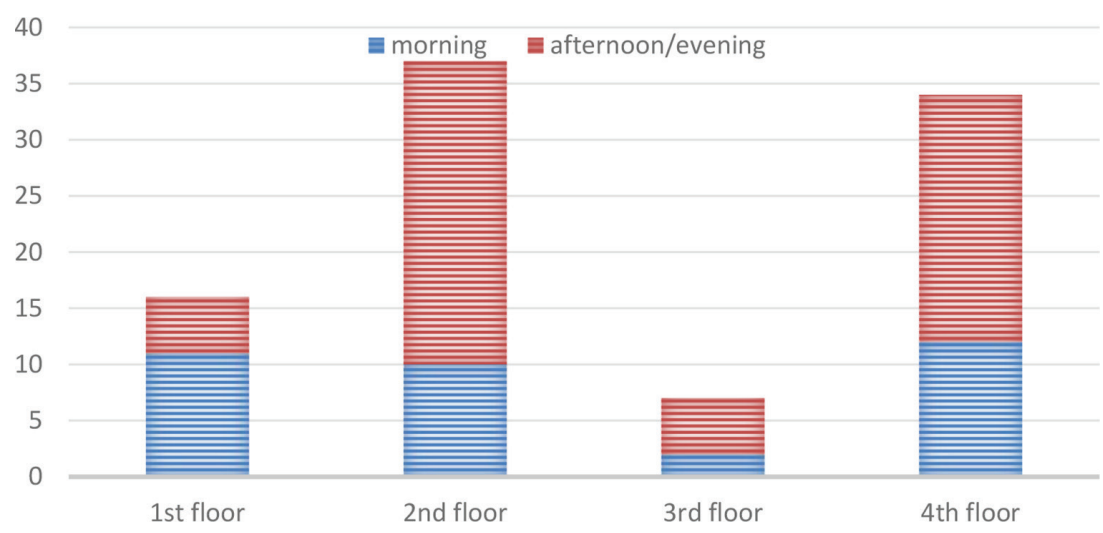

Figure 1: Chart showing occupancy on different floors/different times. 

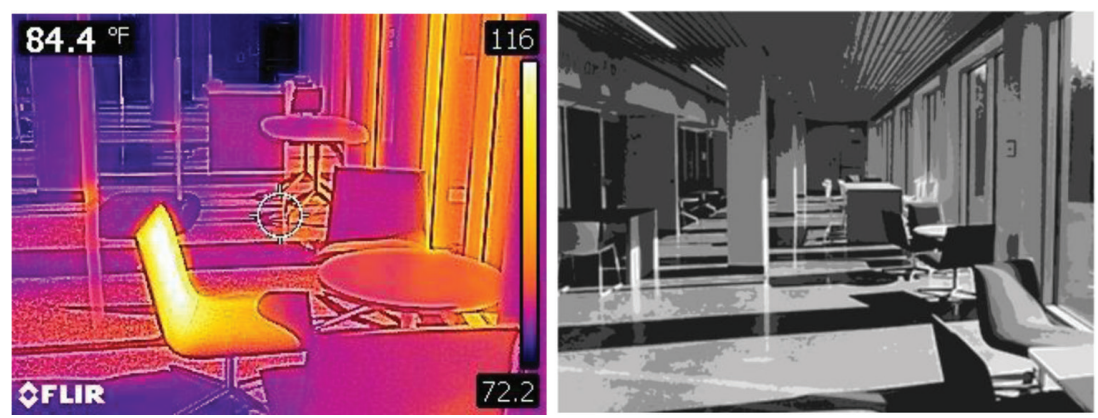

Figure 2: Infrared image and glare analysis for west-facing study space: hot spots and glare are present.

promote glare in the space. To analyse the glare issues, photographs were taken of the study spaces (second and fourth floor) at different times of the day and weather conditions. Glare analysis of the photos using the Schiler method (Cuplite and Rascal) [5] shows that a large amount of glare is experienced on sunny afternoons for this building exposure, ironically, especially where furniture is positioned for people to sit and study (Fig. 2).

To evaluate the daylighting performance of the space, a computer model of the existing fourth floor was created in Revit to run on Sefaira (a cloud-based method for computing energy use and daylighting). The result shows that the west-facing study space is exposed to direct sun throughout the year (Fig. 3a); hence, the excessive heat gain in the space. Even though the average daylight factor of $2.35 \%$ (Fig. 3b) meets with LEED requirements [6], the excessive illuminance level of the space makes it uncomfortable for its users and earns it zero LEED daylighting points.

The online survey and paper questionnaire conducted show that most of the users of this building liked the spatial design of the building and its openness through the transparency of the glass façades, but often find it uncomfortable when the space is very warm and the furniture has absorbed heat. Since the use of the western study lobbies is inevitable especially during the peak hours, we decided to improve the comfort level of the users by proposing shading devices on the western façade of the building to increase the daylighting performance of the study space.

\subsection{Solutions}

With the initial architect's design intent in mind, it was decided to keep the glass façade opened and beautiful as it is. To shade the first and second floor of the western lobbies,
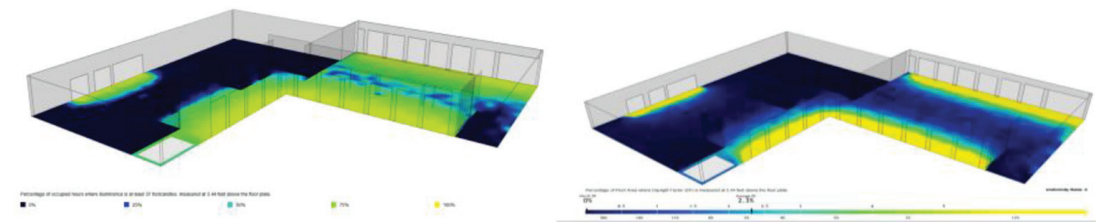

Figure 3: Existing daylight performance - (a) annual exposure to direct sunlight, (b) average daylight factor: high sun exposure in study lobbies. 
planting deciduous trees in the lawn west of the building was proposed to help reduce glare and provide a nature view for the users of the study space.

For the third and fourth floor, light shelves and motorized internal screens were proposed. The light shelves distribute light more evenly in the space by redirecting the direct sunlight on the glass façade to the ceiling, which diffuses it through the space. The external overhang of the light shelves will shade the glass below and reduce the cooling loads. The interior screens will be installed below the light shelves, which may be less effective for the western façade. The screens will allow 50\% daylight in the space and be rendered with beautiful patterns like the existing glass partition walls between the classrooms and the study spaces.

In conclusion, careful analysis of the use of the western study spaces, the hypothesis proved false as the study spaces are used more in the afternoon due to the heavier afternoon class schedule. With the introduction of shading devices, visual and thermal comfort of the users could be achieved and should increase the use of the space for studying (Fig. 4).

\section{GLARE AND MATERIAL: A STUDY OF THE MATERIAL FINISHES ON THE EDUCATION BUILDING IN RELATION TO OCCUPANT COMFORT}

One of the main design drivers for the renovation of the Education Building was that each space had to have views and access to natural daylight. The L-shaped plan form of the Education Building is oriented around a courtyard adjacent to the fully glazed south- and west-facing façades. The circulation hallways with designated study spaces are located along these façades. This plan form allows both direct and reflected late afternoon sun into these interior spaces at low angles. After careful observation and analysis of the lighting conditions, it seems that the material choices implemented in the renovation cause discomfort for the building occupants.

Hypothesis: The reflective material finishes of the interior and exterior of the education building induce glare, causing visual discomfort for occupants.

\subsection{Methodology}

Approaching the building from the southwest, one observes harsh glare from the aluminium façade panelling and the low-e glass curtain wall (both materials reflect light and heat). Inside the building and moving through the hallways at late afternoon hours can be visually unpleasant as sun penetrates the glazing of the south and west façades at a sharp angle near eye level. The polished concrete floor and bare aluminium bounce light off their reflective surfaces and concentrate glare within the interior seating spaces (Fig. 5).

Over the past few months, moving from winter to spring, the Education Building's exposure to natural light in relation to occupant comfort were observed and measured. The study began by recording how, when, and where occupants used the space, along with data related

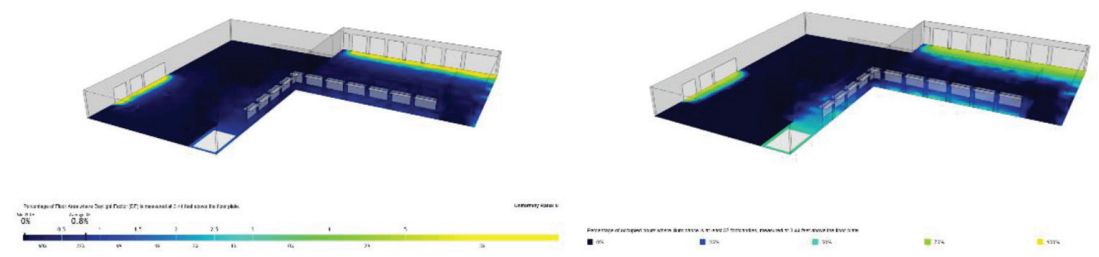

Figure 4: Sefaira analysis after redesign for improved shading - (a) annual exposure to direct sunlight, (b) daylight factor: direct sun greatly reduced. 

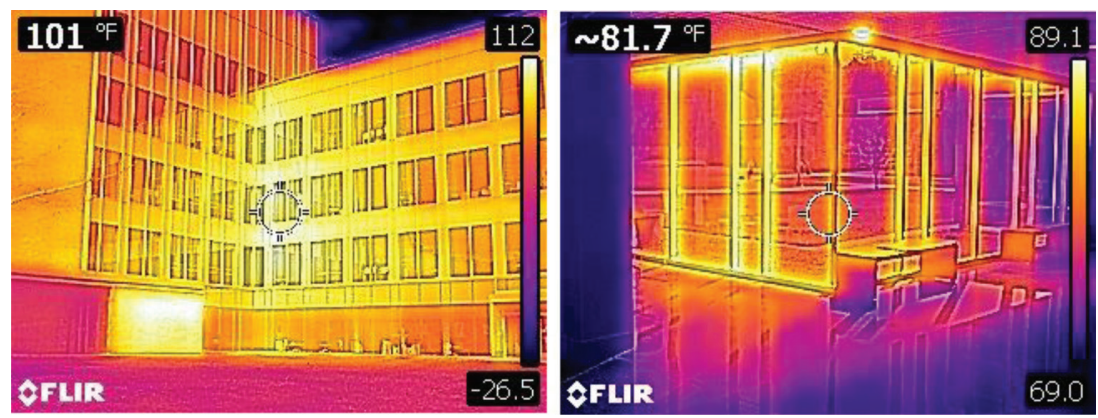

Figure 5: Late afternoon infrared images of glare: external (south- and west-facing curtain walls) and internal (study space along those walls).

to weather conditions. The four lower levels of this building feature seating along the south and west glazed façades, while the fifth level has seating along the south only. While simultaneously observing and recording how people responded to the lighting conditions data loggers were placed near the curtain walls to record the luminous intensity in each level's study space.

\subsection{Results/Analysis}

As seen in the above images (Fig. 5), late afternoon sunlight strikes the highly reflective surfaces of the Education Building at such an angle and intensity as to promote glare, and create an unpleasant thermal and aesthetic experiences. The L-shaped building reflects light and heat into the adjacent façade, thus intensifying the sun's effect.

The data logger results (Fig. 6) show that the seating spaces along both the south and west façades received an intense amount of lighting - above the average visual comfort level, and
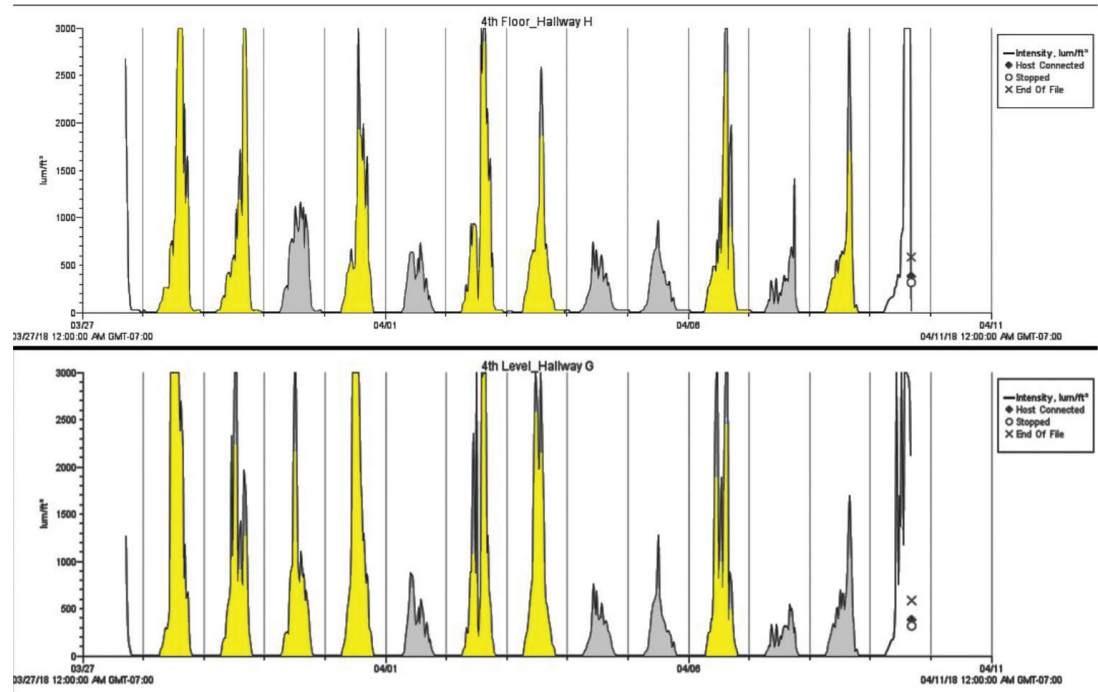

Figure 6: Data logger results: level 4 South $(\mathrm{G})$ and West $(\mathrm{H})$ study space light levels: daily afternoon temperature spikes on sunny days (yellow) in both spaces. 
above what would be expected for early spring. The results also show that usually both westand south-facing spaces are in the direct sun at the same time, negating occupant migration as a strategy for avoiding visual and thermal discomfort.

To investigate the hypothesis of occupant discomfort, additional detailed study space occupancy was recorded - shown in Table 1 . The data demonstrates strikingly low levels of seat occupancy in all areas at all times, particularly the south-facing seats on levels 1 and 5.

Table 1: Occupied Seats along the South and West Facades.

Level,

façade, and

seat count Date, time, weather conditions

Avg. \% of

seats occu-

pied

\section{$\begin{array}{lllllll}\text { T4/17 W4/18 } & \text { M4/23 T4/24 } & \text { T4/24 } & \text { Th5/3 } & \text { F5/4 } & \text { M5/7 }\end{array}$ \\ $8 \mathrm{am}$ noon $5 \mathrm{pm}$ 10am 2am 12pm 9am 4pm \\ $40^{\circ} \mathrm{F} / \quad 55^{\circ} \mathrm{F} / \quad 48^{\circ} \mathrm{F} / \quad 54^{\circ} \mathrm{F} / \quad 70^{\circ} \mathrm{F} / \quad 72^{\circ} \mathrm{F} / \quad 68^{\circ} \mathrm{F} / \quad 65^{\circ} \mathrm{F} /$ \\ $\begin{array}{llllllll}4^{\circ} \mathrm{C} & 13^{\circ} \mathrm{C} & 9^{\circ} \mathrm{C} & 12^{\circ} \mathrm{C} & 21^{\circ} \mathrm{C} & 22^{\circ} \mathrm{C} & 20^{\circ} \mathrm{C} & 18^{\circ} \mathrm{C}\end{array}$ \\ Cloudy Sunny Sun Set Sunny Sunny Sunny Sunny Cloudy}

\begin{tabular}{|c|c|c|c|c|c|c|c|c|c|}
\hline $\begin{array}{l}\text { LVL1 } \\
\text { South } \\
\text { (3 Seats) }\end{array}$ & $0 / 3$ & $0 / 3$ & $0 / 3$ & $0 / 3$ & $0 / 3$ & $1 / 3$ & $0 / 3$ & $0 / 3$ & $1 / 24=04 \%$ \\
\hline $\begin{array}{l}\text { LVL1 } \\
\text { West } \\
\text { (16 Seats) }\end{array}$ & $1 / 16$ & $3 / 16$ & $0 / 16$ & $1 / 16$ & $3 / 16$ & $1 / 16$ & $5 / 16$ & $0 / 16$ & $14 / 128=12 \%$ \\
\hline $\begin{array}{l}\text { LVL2 } \\
\text { South } \\
\text { (11 Seats) }\end{array}$ & $2 / 11$ & $0 / 11$ & $2 / 11$ & $4 / 11$ & $6 / 11$ & $0 / 11$ & $1 / 11$ & $3 / 11$ & $18 / 88=21 \%$ \\
\hline $\begin{array}{l}\text { LVL2 } \\
\text { West } \\
\text { (27 Seats) }\end{array}$ & $0 / 27$ & $5 / 27$ & $13 / 27$ & $2 / 27$ & $8 / 27$ & $10 / 27$ & $0 / 27$ & $15 / 27$ & $53 / 216=25 \%$ \\
\hline $\begin{array}{l}\text { LVL3 } \\
\text { South } \\
\text { (12 Seats) }\end{array}$ & $3 / 12$ & $2 / 12$ & $2 / 12$ & $0 / 12$ & $4 / 12$ & $0 / 12$ & $0 / 12$ & $6 / 12$ & $17 / 96=18 \%$ \\
\hline $\begin{array}{l}\text { LVL3 } \\
\text { West } \\
\text { (25 Seats) }\end{array}$ & $5 / 25$ & $5 / 25$ & $7 / 25$ & $1 / 25$ & $12 / 25$ & $0 / 25$ & $4 / 25$ & $12 / 25$ & $46 / 200=23 \%$ \\
\hline $\begin{array}{l}\text { LVL4 } \\
\text { South } \\
\text { (11 Seats) }\end{array}$ & $1 / 11$ & $4 / 11$ & $0 / 11$ & $0 / 11$ & $6 / 11$ & $4 / 11$ & $0 / 11$ & $2 / 11$ & $17 / 88=19 \%$ \\
\hline $\begin{array}{l}\text { LVL4 } \\
\text { West } \\
\text { (28 Seats) }\end{array}$ & $0 / 28$ & $9 / 28$ & $4 / 28$ & $0 / 28$ & $12 / 28$ & $2 / 28$ & $5 / 28$ & $8 / 28$ & $40 / 224=18 \%$ \\
\hline $\begin{array}{l}\text { LVL5 } \\
\text { South } \\
\text { (5 Seats) }\end{array}$ & $0 / 5$ & $0 / 5$ & $0 / 5$ & $0 / 5$ & $0 / 5$ & $2 / 5$ & $0 / 5$ & $0 / 5$ & $2 / 40=05 \%$ \\
\hline
\end{tabular}


As can be inferred from the low percentages of seats occupied (never greater than $25 \%$ ), the study spaces are not being used as intended in the building program. The pattern of unused spaces correlates to weather conditions; fewer people use the seating during sunny days and more seats are occupied when it is cloudy. Morning occupancy is not dramatically greater than afternoon occupancy because there are more classes in the afternoon.

\subsection{Solution}

Careful analysis and observation of light levels, glare, sun angles, and seat occupancy support the hypothesis that the glare caused by the highly reflective surfaces causes discomfort for the building occupants. A potential solution to this problem would be to implement matte material finishes, thus significantly reducing reflective glare off the surfaces. Overall, this exploration of glare and materiality was a worthwhile exercise in the post occupancy evaluation of the Education Building.

\section{ITEGRATED SHADING- A SOLUTION}

One of the major issues in the Education Building is the lack of visual comfort and excessive heat gain on west- and south-facing curtain walls. Analysis tools such as Sefaira, infrared cameras, and 3-D rendering software, helped determine that the addition of an external shading device to these curtain walls will greatly resolve the issues. This section will show how to solve these issues and bring the Education Building up to its best performance potential. The problem was attacked in an iterative fashion to show the effect of each countermeasure.

\subsection{The issues}

In this study, the research was limited to a single (typical) floor of the Education Building. This floor contains classrooms, offices, conference rooms, and student study space. The focus was on the issues of glare (Fig. 7), thermal heat gain (Fig. 7), and the excessive illuminance (Fig. 8) in the space. The root of each of these issues stems from the direct sunlight on the polished concrete floor, which causes a rise in temperature in the concrete, the furniture, and
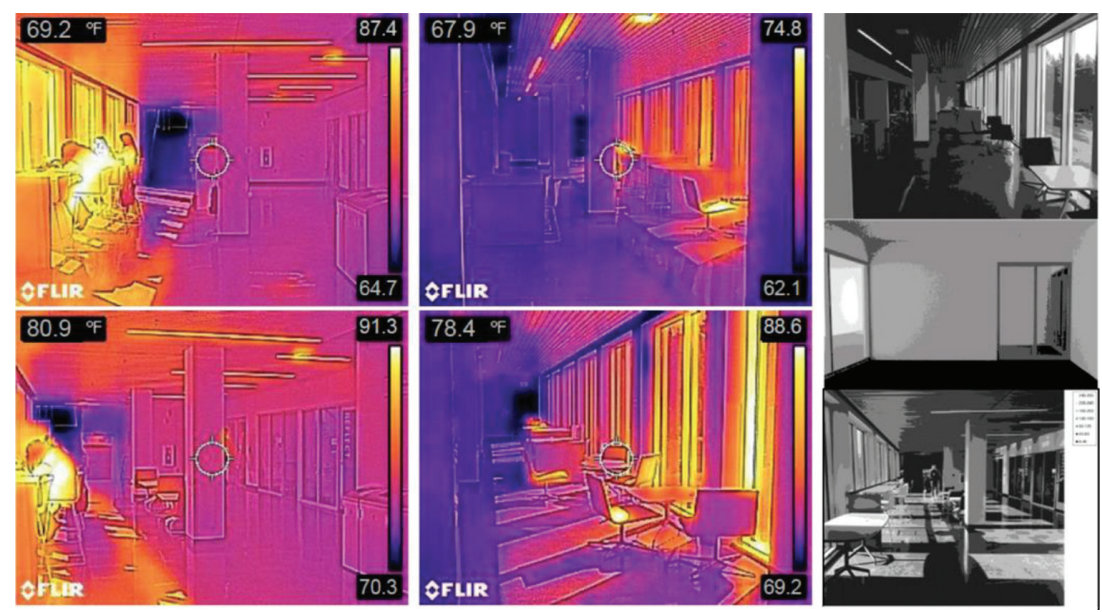

Figure 7: Infrared camera and glare analysis: glare present. 


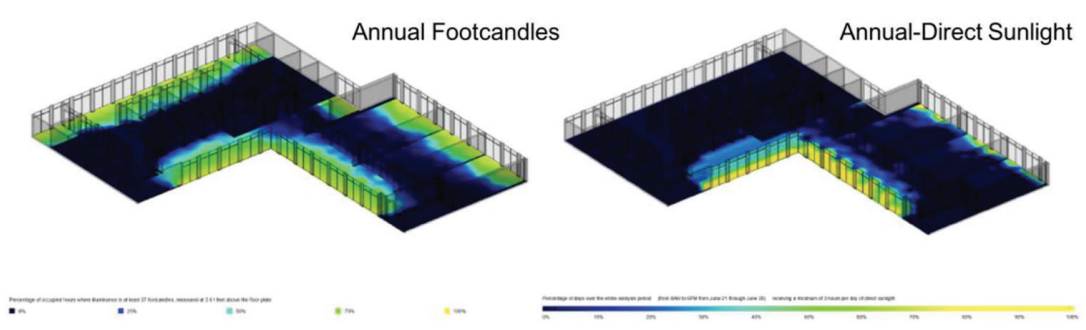

Figure 8: Original Sefaira analysis: considerable direct sun (yellow) in study spaces.

other fittings in the space. The direct sun also reflects off the polished concrete, creating visual discomfort for anyone wishing to linger in the space, and even more for those who have to work in it. Finally, the shear amount of daylight is too bright for the functions the space was designed to accommodate.

\subsubsection{Iteration 1: The light shelf}

The first shading intervention proposed is a light shelf. This would shade the interior from the direct sunlight, and diffuse the ambient light deeper and more evenly into the space. Comparing the original Sefaira analysis (Fig. 8) to the light shelf Sefaira analysis (Fig. 9), it is evident that the light is partially diffused, but glare and heat gain are still major issues.

\subsubsection{Iteration 2: The overhang}

The second shading intervention is an exterior overhang, or horizontal louvre. This combined with the light shelf, will further shade the interior from direct sun, while increasing the surface area for light diffusion into the space. Again, in comparison (Fig. 10), the direct sun penetration was mitigated on the south-facing glazing wall, but not on the west-facing
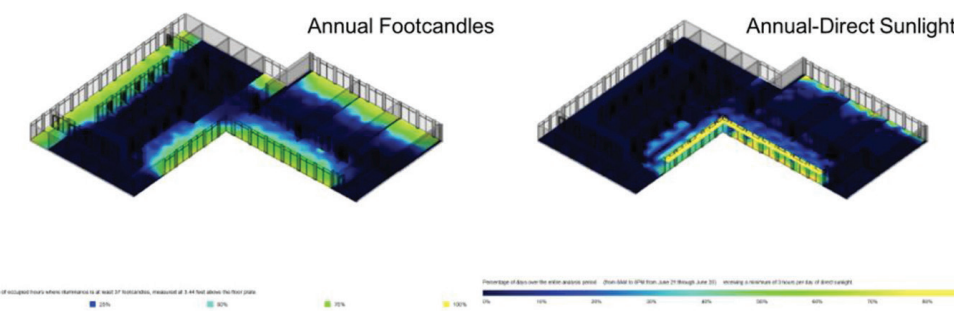

Figure 9: Iteration 1, Sefaira analysis of light-shelf: reduced direct sun.
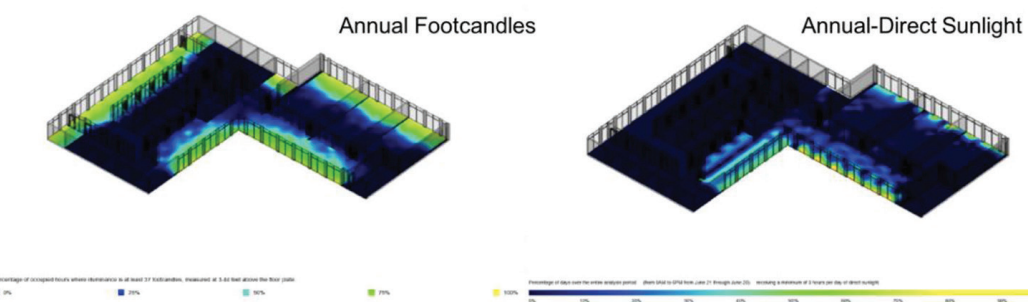

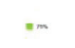

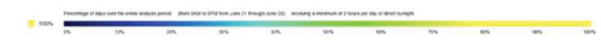

Figure 10: Iteration 2, Sefaira analysis of overhang: reduced direct sun. 
glazing wall. Because of the continued direct sun from lower sun angles, the issues of glare and thermal heat gain are still unresolved.

\subsubsection{Iteration 3: The fin}

The third shading intervention is an exterior vertical fin. This shading device, again combined with the interior light shelf, essentially creates an interior/exterior hybrid egg-crate shading device. The vertical fins diffuse the majority of direct sunlight on the west-facing glazing wall, while the light shelves compensate for that on the south-facing glazing wall (Fig. 11).

\subsubsection{The solution: Integrated shading}

The vertical fin intervention was the most successful in mitigating the direct sunlight on the west-facing façade, but the horizontal louvres were most successful on the south-facing façade. To reconcile the two, the vertical fins and the light shelves were both used, but with elongated the shelves on the south-facing façade to increase the overall overhang (Fig. 12). This solution mitigated the annual direct sunlight exposure to satisfactory levels (Fig 13). With this intervention, the issues of glare, heat gain, and excessive brightness are greatly improved, and there is a greater possibility for visual comfort in the space.

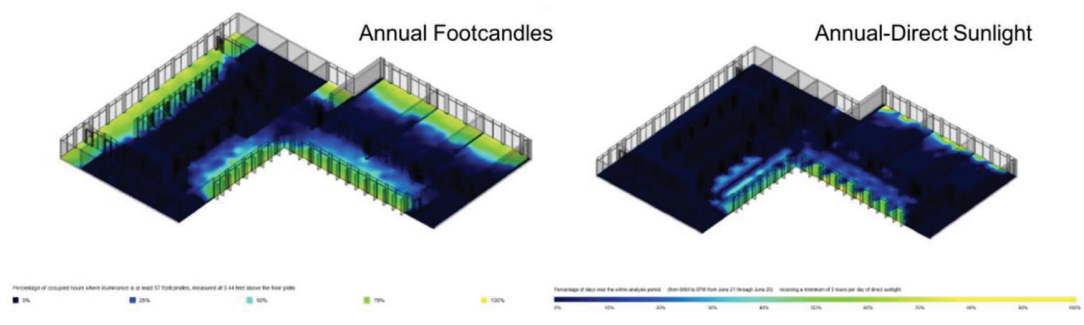

Figure 11: Iteration 3, Sefaira analysis of fin: better daylight, reduced direct sun.

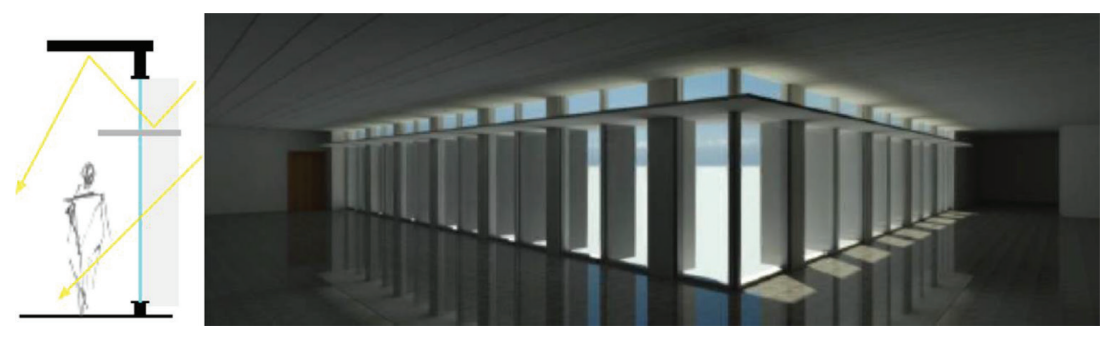

Figure 12: The solution diagram and rendering @ 1pm in April.
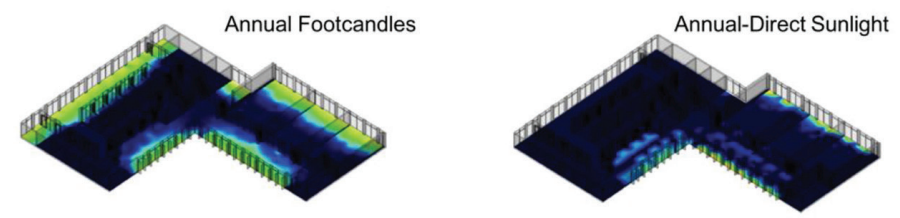

Figure 13: Sefaira analysis of integrated shading: adequate daylight, much reduced direct sun. 


\section{CONCLUSION}

Previous work detected a more problems with the lighting and energy efficiency for the Education Building than for the IRIC [1], [2]. Investigators wanted to determine if these lighting and thermal problems were both substantial and perceived by the Education Building occupants. They found that the spaces designed for accommodating students' studying were greatly impacted by direct solar gain, which was compounded at times by sun reflected from the L-shaped building's curtain wall - heat- and light-reflective aluminium and low-E glazing. Observation of study space use revealed a distinct lack of enthusiasm - low occupancy. Other communal study spaces on campus are highly occupied. An attempt to determine why the Education Building spaces are avoided via a user survey tool, ROAST [7], proved futile, but telling, as only one respondent to the survey was located the study spaces. In conclusion, the environmental characteristics of the study spaces do not support their design intent.

The investigative teams also wanted to discover if the obvious sun penetration and glare issues could be mitigated in a manner sympathetic to the architect's design intent of having '...natural light penetrate all spaces.' It was found that an aggressive use of external shading devices (vertical fins) and light shelves could mitigate the direct solar penetration while maintaining access to daylight and views to the exterior courtyard.

While IRIC revels in its ecological fit - it has a green roof beside its wide access stairway and rain gardens as well as a superior daylighting and solar control scheme. The Education Building uses existing trees on the East and North exposures to provide shading while it leaves the fully glazed South and West façades open to sun, light, and view. Because of solar gain and glare issues, the study spaces adjacent to these façades are disused and the potential connection to the exterior environment is tenuous. Moreover, this connection is solely visual; the building does not actively engage the environment. Although both buildings have achieved LEED Gold, IRIC is far more ecologically integrated. Our findings echo Mark Skelly's warning that, 'BREEAM (LEED in our case) plays an important role in the industry, but it is no substitute for a thoughtful iterative briefing and design process' [8].

Further study, perhaps through interviews, should be undertaken to determine users' motivation for avoiding use of the study spaces. There are more well-used study spaces in the Idaho Commons and in IRIC, so comparing users' perceptions of these spaces may prove fruitful. Also, a life-cycle cost analysis should be performed on proposed modifications to the Education Building's south- and west-facing curtain walls to determine long term benefit.

\section{ACKNOWLEDGEMENTS}

Thanks to Keiran-Timberlake Architects for allowing us to beta test their cloud-based occupant survey software, ROAST.

\section{REFERENCES}

[1] Brannan, M.L., Coleman, M.J., Escalante, L.A., Greene, B.T.N., Haglund, B.T., Kuipers, H.R., Lui, X., Lundgren, W.R. \& Yin, L., New buildings, new lighting, new critique: student analysis of integrating daylight and LED lighting. PLEA 2018 Design to Thrive Proceedings Vol. II; Network for Comfort and Energy Use in Buildings, pp. 3167-3174, 2017.

[2] Brannan, M.L. \& Haglund, B.T., Integrated Daylight and LED Lighting: A Student Research Project, Presented at Professional Lighting Design Convention, Paris, France, 2017.

[3] Roberts, T., The future is wide open, Here We Have Idaho. Moscow: University of Idaho, 2016. 
62 F. D. F. Baja, et al., Int. J. of Design \& Nature and Ecodynamics. Vol. 14, No. 1 (2019)

[4] Stormo, A., The Future is Bright, Here We Have Idaho. Moscow: University of Idaho, 2016.

[5] Schiler, M.E. \& Japee, S., Protocols for Video Photometry using the Luminance Distribution Method. Interior Illuminance, Daylight Controls, and Occupant Response, Vital Signs Project, University of California, 1995.

[6] Kwok, A.G. \& Grondzik, W.T., Lighting; The Green Studio Handbook, Routledge: New York, pp. 84-87, 2018.

[7] ROAST Survey Online, https://www.roastsurvey.com/ (accessed 25 May, 2018).

[8] Doors and Windows, Vitsœ HQ by Vitsœ with Martin Francis and Waugh Thistleton, AJ Specification 12:17, December, 2017. 